1982

\title{
Capital Punishment and Lethal Assaults Against Police
}

William C. Bailey

Cleveland State University, w.bailey@csuohio.edu

Follow this and additional works at: https://engagedscholarship.csuohio.edu/clsoc_crim_facpub

Part of the Criminology Commons, and the Law Enforcement and Corrections Commons

How does access to this work benefit you? Let us know!

\section{Original Citation}

Bailey , W. C. (1982), Capital punishment and lethal assaults against police. Criminology, 19, 4, 608-625. doi: 10.1111/j.1745-9125.1982.tb00441.x

\section{Repository Citation}

Bailey, William C., "Capital Punishment and Lethal Assaults Against Police" (1982). Sociology \& Criminology Faculty Publications. 40.

https://engagedscholarship.csuohio.edu/clsoc_crim_facpub/40

This Article is brought to you for free and open access by the Sociology \& Criminology Department at EngagedScholarship@CSU. It has been accepted for inclusion in Sociology \& Criminology Faculty Publications by an authorized administrator of EngagedScholarship@CSU. For more information, please contact library.es@csuohio.edu. 
This investigation provides a multivariate analysis of the deterrent effect of the death penalty on the rate of lethal assaults against the police. Examining statelevel data for the period 1961 to 1971, we hypothesize a significant inverse relationship between the rate of police killings and (I) the statutory provision for capital punishment and (2) the execution rate of convicted murderers. Contrary to the deterrence hypotheses, no support is found for the argument that the provision and use of the death penalty provides an added measure of protection for the police. Rather, variation in police killings rates, like the general homicide rate, would appear to be largely a function of various sociodemographic factors.

\title{
CAPITAL PUNISHMENT AND LETHAL ASSAULTS AgAinst POLICE
}

\author{
WILLIAM C. BAILEY
}

Cleveland State University

he deterrent effect of the death penalty has been a question of continuing debate in this country. While most social scientists have long concluded that capital punishment does not provide an effective deterrent to murder, this question has once again become a lively topic of concern in the professional literature. Beginning in the mid-1970s, a number of important questions started to be raised about the theoretical and methodological adequacy of the classic deterrence and death penalty studies that uniformly failed to support the deterrence argument. While it is beyond the scope of this article to provide a detailed review and critique of these early investigations, we will briefly examine their various shortcomings, because these limitations have a direct bearing on the topic of the present research: deterrence, the death penalty, and lethal assaults on police.

\section{EARLY DEATH PENALTY INVESTIGATIONS}

Social scientists traditionally have drawn a negative conclusion about the deterrent effect of the death penalty based upon studies of two sorts: 
(1) longitudinal analyses of homicide rates in jurisdictions before and after the abolition and/or reinstatement of capital punishment and (2) comparative analyses of homicide rates for abolitionist and retentionist jurisdictions. Contrary to the deterrence hypothesis, these studies have typically shown (1) no significant change in homicides that can be attributed to the abolition or reinstatement of capital punishment and (2) homicide rates to be the same or even higher in death penalty jurisdictions (Reckless, 1969; Bedau, 1967; Sellin, 1959, 1967; Schuessler, 1952; Dann, 1935; Vold, 1932; Kirkpatrick, 1925; Sutherland, 1925; Bye, 1919).

For decades, these studies brought most students of the death penalty to what Sellin (1967: 138) has termed the "inevitable" conclusion. "The death penalty - in law or practice - does not influence homicide death rates." In recent years, however, serious questions have been raised about the conclusiveness of the evidence from these studies. First, critics have pointed out that a simple comparison of homicide rates for death penalty and abolitionist jurisdictions hardly provides an adequate test of the deterrence question (Jeffery, 1965; Van den Haag, 1969, 1975; Bailey, 1974, 1975; Ehrlich, 1975). Such comparisons ignore the role of various social, economic, demographic, and cultural factors that have long been identified with variation in homicide rates. ${ }^{1}$ In addition, the same arguments have been voiced about the adequacy of longitudinal studies of the bivariate relationship between capital punishment and homicide rates. Importantly, changes in homicide rates may result from changes in factors other than the provision/nonprovision for the death penalty.

Second, while the deterrence doctrine emphasizes the importance of the certainty of sanctions as a means of crime control, the deterrent effect of the certainty of execution was a neglected question in most early studies (Gibbs, 1977). As a result, these investigations are seriously flawed because no attention was paid to the substantial variation in the actual level of executions (execution rates) in death penalty states. Recognizing this limitation, Sellin (1959: 275-276) has long argued that we need to focus upon the certainty of executions, not simply statutes, for "were it (the death penalty) present in the law alone it would be completely robbed of its threat."

\section{RECENT DEATH PENALTY INVESTIGATIONS}

The mid-1970s witnessed the beginning of a new round of deterrence and death penalty research aimed at avoiding the limitations noted 
above by (1) considering a wide variety of sociodemographic control variables in comparing homicide rates cross-sectionally and longitudinally for death penalty and abolitionist jurisdictions; (2) introducing the certainty of execution in both interstate and time-series analyses of the deterrence hypothesis; and (3) incorporating the certainty and severity of imprisonment for homicide as alternative legal sanctions.

With but one exception (Ehrlich, 1975), these studies have revealed a very consistent pattern of findings. ${ }^{2}$ First, when death penalty and abolitionist states have been matched on a variety of sociodemographic factors, homicide rates tend to be higher for the former jurisdictions (Bailey, 1975; Baldus and Cole, 1975). Second, both interstate and time-series analyses have failed to detect a significant inverse relationship between the certainty of execution and homicide rates when a wide variety of control variables have been considered (Bowers, 1974; Bowers and Pierce, 1975; Passell and Taylor, 1976; Bailey, 1974, 1975, 1977, 1978, 1979-1980; Forst, 1977; Black and Orsagh, 1978; Kleck, 1979).

In sum, this new round of death penalty research has examined a number of important questions, and the conclusion would appear to be the same as that reached by Sellin (1959) over two decades ago. There is no evidence that the death penalty - in law or in practice - provides an effective deterrent to murder. Importantly, however, recent investigators have completely ignored one question that is perenially raised whenever the abolition of capital punishment is discussed: does the death penalty provide an added measure of protection for the police in the performance of their duties? In other words, is policing more hazardous in abolitionist and retentionist jurisdictions where the execution rate of convicted murderers is low?

Despite the obvious importance of these questions, these issues have been largely ignored by death penalty investigators. Only a single investigation by Sellin (1955) has attempted to address empirically these questions, and his study is now quite dated. ${ }^{4}$ Moreover, Sellin's comparative analysis of the rate of police killings (1919 to 1954) for death penalty and abolitionist states suffers from the same limitations noted above with early examinations of homicide rates in the two types of jurisdictions. Importantly, Sellin failed to (1) consider how variation in execution rates for murder in retentionist states may influence the rate of police killings, and (2) introduce the necessary control variables in his analysis to properly isolate the possible deterrent effect of the death penalty on the rate of police killings.

Although Sellin may be correct that the death penalty and the rate of police killings are independent factors, this conclusion cannot reasona- 
bly be drawn from his study. Rather, a sound understanding of this question must await the adoption of a more detailed and sophisticated methodology than that found in Sellin's pioneering investigation.

\section{THE PRESENT INVESTIGATION}

In this study, we provide a detailed multivariate analysis of the rate of lethal assaults on the police (hereafter referred to as police killings). Our concern here is to build upon the limitations of the Sellin study by providing a more adequate test of the hypothesis that both the statutory provision for capital punishment and the actual use of the death penalty provide effective deterrents to police killings. Rather than considering solely the bivariate relationship between the death penalty and police killings, we incorporate into the analysis various factors (control variables) associated with police killings in order to isolate the possible deterrent effect of the death penalty.

Consistent with the deterrence argument, two hypotheses are advanced: (1) the rate of police killings is significantly lower in death penalty than abolitionist jurisdictions; and (2) there is a significant inverse relationship between the certainty of execution for murder and the rate of police killings. Due to data constraints, this study is confined to a yearly cross-sectional analysis of the 50 states for the period 1961 to 1971. Required figures on police killings for individual states are not available before 1961. State-level figures on police killings are available from the FBI since 1971, but this period was excluded from the analysis. With the United States Supreme Court's (1972) ruling in Furman v. Georgia, the legal status of capital punishment became uncertain for the next few years in many jurisdictions. ${ }^{5}$

\section{METHODS AND PROCEDURES}

\section{POLICE KILLINGS}

The dependent variable for this investigation is the rate of police killings. To construct this measure, figures were required on the number of police officers killed in each state from 1961 to 1971 . These data were secured from unpublished figures compiled by the FBI. ${ }^{6}$ Included in these figures are police killings resulting from lethal assaults; excluded are deaths resulting from accidents or other causes. 
To compute police killing rates, figures were also required on the number of full-time equivalent police officers in each state for each year. These data were secured from annual publications issued by the Department of Commerce, Bureau of the Census, and were then used to compute police killing rates per 1000 police officers for each state and year.

\section{THE DEATH PENALTY}

For each year, states were classified as either death penalty or abolitionist jurisdictions. ${ }^{7}$ In addition, execution rates for murder were computed for each death penalty state by dividing (1) the total number of executions for murder each year by (2) the total number of reported murders during the year. For ease of interpretation, execution rates were converted from proportions ( 0 to 1.0 ) into percentages ( 0 to $100 \%)$. Execution and murder data were secured, respectively, from publications issued by the Federal Bureau of Prisons and Investigation. ${ }^{8}$ While it would have been of interest to also compute an execution rate measure based upon the number of police killings and the number of executions for police killings, execution data for this type of offense are not available from the Bureau of Prisons. Our measure of the certainty of execution does provide, however, a general indicator of the willingness of a state to put convicted murderers to death.

\section{CONTROL VARIABLES}

Our review of the literature has failed to identify a theory of police killings. However, the literature does indicate that certain sociodemographic factors are associated with rates of police homicide, factors that have also been considered by some recent investigators in more general examinations of the deterrence and death penalty hypothesis. ${ }^{9}$ To isolate the effect of capital punishment on police killings, the following factors are considered in the analysis as control variables: (1) percentage of urban population, (2) percentage of nonwhite population, (3) percentage of families below the poverty level, and (4) percentage of unemployment of the civilian labor force. Data for these variables came from figures issued by the Department of Commerce, Bureau of the Census. ${ }^{10}$ 


\section{ANALYSIS}

To examine the hypothesis that the statutory provision for capital punishment and the certainty of execution provide effective deterrents to police killings, we first examined the bivariate relationship between each death penalty variable and annual police killing rates. Second, to control for the possible spuriousness of these findings, both death penalty variables, the control variables, and rates of police killings were entered into a series of multiple regression analyses for each year. For 1968 to 1971, execution rates could not be considered in the analysis, since there were no executions for murder during this period."

\section{FINDINGS}

\section{BIVARIATE ANALYSIS}

Table 1 reports average police killing rates for death penalty and abolitionist states for 1961 to 1971. As discussed above, the deterrence hypothesis would predict significantly higher police killing rates in jurisdictions without the death penalty, but this expectation is not borne out in Table 1. For six of the eleven years ( $54.5 \%)$, average police killing rates were higher for abolitionist than retentionist jurisdictions, but regardless of the year considered, the offense rates are very similar, and they are not significantly different for the two types of jurisdictions. These findings lend no support to the deterrence hypothesis.

Table 2 reports the bivariate correlations between police killing rates and the status of the death penalty (column 2) and execution rates (colume 3). (In this analysis, abolitionist states are treated as having zero execution rates.) As one would predict from Table 1, the findings are mixed for the relationship between offense rates and the status of the death penalty. With death penalty states given a weight of one and abolitionist states a weight of zero, we would expect a significant inverse relationship between this variable and police killings. ${ }^{12}$ For six of the eleven years (1963 to 1968), the correlations fall in the predicted negative direction, but they are very slight and are not statistically significant. For the remaining five years, the correlations are positive and indicate police killings to be higher in death penalty jurisdictions. ${ }^{13}$ 
TABLE 1

Average Police Killing Rates for Abolition and Death Penalty States

\begin{tabular}{lcccc}
\hline Year & $\begin{array}{c}\text { Abolition } \\
\text { States }\end{array}$ & $\begin{array}{c}\text { Death Penalty } \\
\text { States }\end{array}$ & $\begin{array}{c}\text { Al1 } \\
\text { States }\end{array}$ \\
1961 & .039 & .098 & .089 \\
1962 & .021 & .179 & .157 \\
1963 & .331 & .239 & .252 \\
1964 & .238 & .218 & .221 \\
1965 & .294 & .203 & .221 \\
1966 & .330 & .233 & .252 \\
1967 & .310 & .223 & .240 \\
1968 & .293 & .168 & .193 \\
1969 & .177 & .202 & .197 \\
1970 & .135 & .171 & .164 \\
1971 & .148 & .308 & .276 \\
\hline
\end{tabular}

The figures presented in column 3 of Table 2 are inconsistent with the hypothesis of a significant inverse relationship between execution rates and police killing rates. For five of the seven years where this question can be examined, the correlations are in the predicted negative direction. The negative coefficients are very low, however, and are not statistically significant. For two of the seven years (1961 and 1962), the correlations are positive, the opposite direction than hypothesized.

\section{MULTIVARIATE ANALYSIS}

The above findings do not support the argument that the death penalty provides an effective deterrent to police killings, but these negative findings may be biased (spurious) due to a failure to properly control for other factors associated with police killings. This question is examined in Table 3 where police killing rates are regressed against the death penalty and control variables.

To reiterate, if capital punishment does provide an effective deterrent to police killings, we would expect a significant inverse relationship 
TABLE 2

Zero-Order Correlations Between Rate of Police Killings and Death Penalty Status and Execution Rates, by Year

\begin{tabular}{lcc}
\hline Year & $\begin{array}{c}\text { Death Penalty } \\
\text { Status }\end{array}$ & $\begin{array}{c}\text { Execution } \\
\text { Rate }\end{array}$ \\
\cline { 2 - 3 } 1961 & .121 & .137 \\
1962 & .227 & .175 \\
1963 & -.081 & -.067 \\
1964 & -.020 & -.062 \\
1965 & -.124 & -.153 \\
1966 & -.086 & -.179 \\
1967 & -.082 & -.083 \\
1968 & -.141 & $\star \star \star \star$ \\
1969 & .045 & $\star \star \star \star$ \\
1970 & .069 & $\star * \star \star$ \\
1971 & .215 & $\star \star \star \star$
\end{tabular}

$\star * \star *$ No executions were performed during the period 1968 to 1971 .

between (1) the provision for the death penalty and police killing rates and (2) execution rates and the rate of police killings. Neither of these predictions are supported by Table 3. First, for three of the eleven years, there is an inverse relationship between police killings and the provision for the death penalty, but the negative coefficients are very slight and are not statistically significant. For the remaining eight years, the death penalty is associated with a higher level of police killings.

Second, for a majority of years (1963-1967), an increase in execution rates is associated with a lower rate of police killings. For none of the five years, however, are the results statistically significant. In each case, the negative coefficient is very slight for the certainty of execution.

Third, the insignificant effect of capital punishment on police killings is further reflected by a comparison of the beta coefficients for the death penalty and control variables. If the size of the betas are rank ordered for each year, and these ranks are averaged over the eleven-year period for each variable, the following pattern results (from best to least adequate 


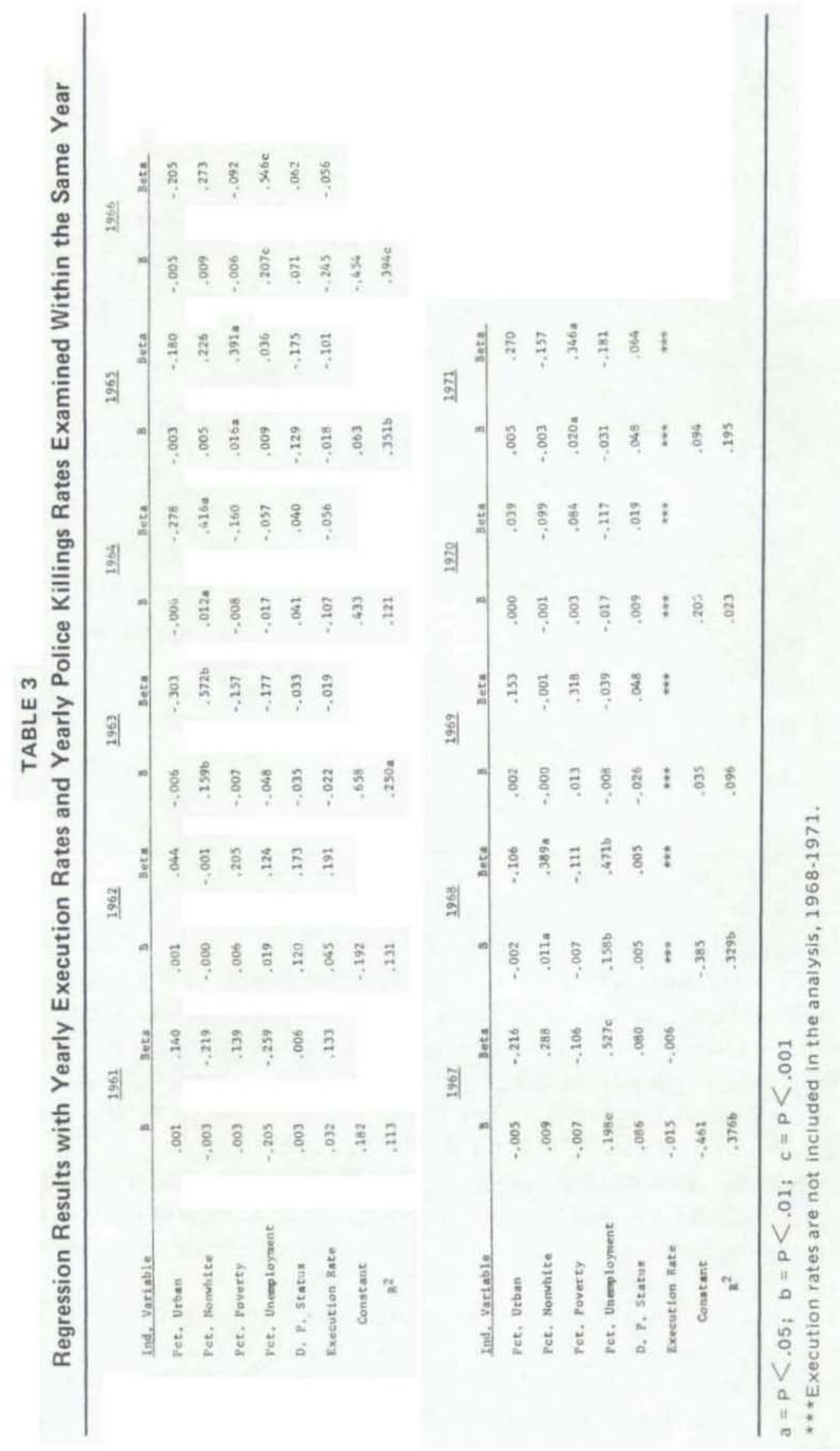


predictor of police killings): (1) poverty; (2) nonwhite population and unemployment tied for second; (3) urban population; (4) execution rate; and (5) provision for capital punishment. In short, of the six variables considered, the two death penalty variables are the poorest predictors of police killings.

\section{A TIME-LAG ANALYSIS}

In the above analyses (Tables 2 and 3), execution rates and the rate of police killings were examined within the same year. The rationale is that execution rates have an immediate (within the same year) effect on police killings. The possibility exists, however, that executions may have a delayed deterrent effect that was not captured in the above analysis. To assess both the immediate and possible delayed effects of executions, we next examine the relationship between yearly execution rates and average police killing rates for two-year periods (year $t+$ year $t+1) / 2$. This analysis is simply a replication of that reported in Table 3 , but with a new measure of police killings. Results are reported in Table 4.

This analysis reveals a similar pattern to that found in Table 3 . Neither of the death penalty variables are related significantly to the average rate of police killings. First, for a majority ( 7 out of 11) of years, the provision for the death penalty is positively associated with police killing rates (i.e., police killings are more common in retentionist jurisdictions). For the remaining four years, the provision for capital punishment is negatively associated with police killings, but the relationship is very slight and not statistically significant.

Second, for four of the seven years where execution rates can be considered, this variable is positively associated with police killings. Conversely, higher execution rates are associated with lower rates of police killings for three time periods, but the relationship between these two factors is very slight and not statistically significant.

Third, the beta results also indicate the same pattern as found in Table 3. Rank ordering the beta coefficients for each year, and averaging the ranks over the eleven-year period, the two death penalty variables are again the poorest predictors of police killing rates: (1) nonwhite population; (2) urban population; (3) poverty and unemployment tied for third; (4) provision for capital punishment; and (5) execution rates. In short, this analysis also provides no support for the deterrence hypothesis. 
TABLE 4

Regression Results with Yearly Execution Rates and Two-Year Mean Rates of Police Killings

\begin{tabular}{|c|c|c|c|c|c|c|c|c|c|c|c|c|}
\hline \multirow[b]{2}{*}{ Ind Varlable } & \multicolumn{2}{|c|}{$\underline{1961-62}$} & \multicolumn{2}{|c|}{$1962-63$} & \multicolumn{2}{|c|}{$1963-64$} & \multicolumn{2}{|c|}{$1964-65$} & \multicolumn{2}{|c|}{$\underline{1965-66}$} & \multicolumn{2}{|c|}{$\underline{1966-67}$} \\
\hline & 3 & Beta. & 1 & Bata & 3 & Bere & 1 & Hete. & $1 \quad 1$ & Beta & 8 & Beta. \\
\hline Pet. Urban & .001 & .089 & -.002 &,- 201 & $-.006 \mathrm{x}$ & -.376 & -.004 & -.278 &.,$- 006 b$ & $-.383 \mathrm{~b}$ & -.005 & -.209 \\
\hline Pet Nonvitite & -.002 & -.129 & $.008 b$ & $.492 b$ & $.014 \mathrm{c}$ & $.670 \mathrm{c}$ & $.008 \mathrm{a}$ & .4294 & $.009 b$ & $.451 \mathrm{~b}$ & .009 & $.2 \pi$ \\
\hline Pet. Poverty & .004 & .218 & -.000 & -.012 & -.007 & -.211 & .003 & .104 & .002 & .047 & -.006 & -.086 \\
\hline Pet, Unasployment &,- 009 &.,- 102 & -.001 & -.007 & -.024 & -.123 & .010 & .046 & $.084 b$ & .3606 & $.200 \mathrm{e}$ & $.540 c$ \\
\hline D.p. Status & $.0 n$ & .163 & .043 & .069 & .001 & .001 & -.062 & -.088 &. .034 & -.049 & .069 & .063 \\
\hline Execution Rate & .018 & .084 & .031 & .143 & -.071 & -.065 & .112 & .085 & -.027 & -.165 & -.242 & -.057 \\
\hline Constant. & .036 & & .138 & & .500 & & .174 & & -.066 & &.- .434 & \\
\hline $\mathrm{R}^{2}$ & .099 & & .209 & & $.324 b$ & & $.263 a$ & & .4676 & & $.390 \mathrm{c}$ & \\
\hline & $1967=$ & & 1968. & -69 & 1969. & & 1970 & -21 & $1971-7$ & & & \\
\hline In. Vartable & $x$ & Setes & 8 & Aete & 8 & sets & 2 & Sets & 3 & Beta. & & \\
\hline Pet. Urban &,- 004 & -.199 & -.000 & -.015 & .001 & .102 & .003 & .229 & $-.005 a$ &.,$- 376 \mathrm{a}$ & & \\
\hline Pet. Mornhite & $.010 a$ & $.369 a$ & .006 a & .340 &,- 001 & -.054 & -.002 &,- 178 & .001 & .083 & & \\
\hline Pet, Poverty & -.006 & -.111 & .002 & $.05 s$ & .008 & .270 & .013 & .338 & .006 & .145 & & \\
\hline Pet. Uneoployment & $.169 \mathrm{c}$ & $.519 e$ & $.078 b$ & .3996 & -.022 & -.137 & -.027 & -.187 & -.029 & -.236 & & \\
\hline D.P. Statur & .035 & .037 & -.008 & $=.014$ & -.013 &,- 031 & .028 & .058 & .065 & .122 & & \\
\hline Execution Rate & .109 & .051 & $m$ & $\cdots$ & $+\infty$ & $\cdots$ & $\cdots$ & $\cdots$ & $\cdots$ & $m$ & & \\
\hline Conatant & -.388 & & -.187 & & .145 & & .133 & & .454 & & & \\
\hline $\mathrm{R}^{2}$ & $.391 \mathrm{e}$ & & .287 & & .072 & & .157 & & $.247 \mathrm{a}$ & & & \\
\hline
\end{tabular}

$\mathrm{a}=\mathrm{p}<.05 ; \mathrm{b}=\mathrm{p}<.01 ; \mathrm{c}=\mathrm{p}<.001$

$* *$ Execution rates are not included in the analysis, 1968-1972. 


\section{AN ALTERNATIVE TIME-LAG MODEL}

In the above analysis, the deterrent effect of the certainty of the death penalty was assessed by examining yearly execution rates: the ratio of (1) the number of executions for murder during each year to (2) the number of reported murders during each year. This measure of executions is based on the assumption that during any given year, the public has a general awareness of the ratio of murders to executions for murder. The possibility exists, however, that the public's impression of the certainty of the death penalty is not based upon murders and executions during any one year, but rather upon murders and executions during the past few years.

To explore this possibility, a three-year average execution rate measure was computed, (year $\mathrm{t}+\mathrm{t}-1+\mathrm{t}-2$ )/ 3 , and substituted in the regression analysis. To illustrate, in considering police killings for 1961, average execution rates were examined for the period 1959 to 1961 , and so on, with finally 1967 police killing rates and average execution rates for the period 1965 to 1967 being examined. Police killings from 1968 to 1971 were not examined since there were no executions for murder during this period.

The results of this analysis parallel very closely the earlier analysis and can be summarized very briefly without presenting the findings in tabular form. First, for all but two years (1963 and 1965), the provision for capital punishment is positively associated with rates of police killings. Regardless of the direction of the relationship between these two factors, however, the results are not statistically significant. Second, for all but one year (1962), average execution rates and police killing rates are negatively associated, but the execution rate coefficients are very low and none are statistically significant. Third, like that found in the earlier analyses, each of the control factors is rather consistently a better predictor of police killings than either of the death penalty variables.

In sum, this analysis also reveals no evidence that the death penalty provides an effective deterrent to police killings. Nor is this finding altered when three-year execution rates and two-year police killing rates (as used in Table 4) are considered in a further analysis.

\section{SUMMARY AND CONCLUSION}

In this investigation we have examined an important but largely neglected question in the deterrence literature. Does the provision for 
capital punishment and its use provide an effective deterrent to police killings? While police spokesmen have long taken the position that capital punishment does deter murder and that the death penalty does provide an added measure of protection for police, social scientists have reached the opposite conclusion. ${ }^{14}$ Although there is substantial empirical evidence that seriously questions the former claim, the question of capital punishment and police safety has been largely ignored by previous investigators. Our review of the literature reveals only a single empirical investigation of this question (Sellin, 1955), but this study must be viewed with extreme caution due to its previously noted limitations.

To extend our understanding of this important question, we have incorporated into our analysis of capital punishment and police killings a number of the theoretical and methodological innovations found in recent deterrence and death penalty investigations. Consistent with the deterrence argument, two hypotheses were examined: (1) the provision for the death penalty has a significant deterrent effect on police killings, and (2) there is a significant inverse relationship between the certainty of the death penalty and police killings. To control for possible spuriousness, control factors were introduced into the analyses, and various models of the execution rate-police killing rate relationship were considered. State-level data for eleven individual years (1961-1971) were examined in considering the hypotheses.

The analysis provided a rather clear-cut pattern of findings. First, no consistent relationship was observed between the provision for capital punishment and the rate of police killings. For some years offense rates were higher in abolitionist jurisdictions, and for other years - a majority of years - the pattern was reversed. Regardless of the year considered, however, the provision for the death penalty was not significantly related to police killings. Second, no support was found for the hypothesis of a significant inverse relationship between the certainty of the death penalty and police killings. For some years these two factors are negatively associated as the deterrence hypothesis predicts, but the results are not statistically significant. Moreover, regardless of the sign of the execution rate coefficient, there is only a very slight relationship between the certainty of the death penalty and the rate of police killings. This pattern held regardless of the execution and police killing rate measures considered and the type of time-lag utilized. Finally, each of the control variables rather consistently proved to be a better predictor of police killings than either death penalty variable.

In sum, does the death penalty provide an added measure of protection for the police against lethal assaults? ${ }^{15}$ Our findings would suggest 
the negative. We find no evidence that either the provision for capital punishment or its actual level of use is an effective deterrent to police killings.

In conclusion, we are in total agreement that policing is a hazardous profession in this country, and that it is quite understandable for many police spokesmen to favor the retention and use of the death penalty as a means of protecting their ranks. After all, what profession would not be committed to legislation and a penal policy believed to protect its members, as well as the general public, from injury and death? On both counts, however, the evidence is clearly negative. Not a single reputable study has yet to show capital punishment to be an effective deterrent to murder, nor does the present investigation provide any support for the contention that the death penalty provides an added measure of protection against police killings.

Without question, the high rate of police killings is a serious problem, and one in obvious need of attention. There is no indication, however, that capital punishment provides a viable, or even a partial, solution to this problem. Rather, we are in agreement with the conclusion reached by Creamer and Robin (1970: 493) and many others who have studied police assaults. "The greatest burden of responsibility for preventing assaults on police must fall upon the police themselves. ... Paramount in solving the assault of police problem is the great need for special training of police officers. . . to anticipate and handle potential assaults." (FBI figures have revealed consistently since the early $1960 \mathrm{~s}$ that the vast majority of police killings result from attempts to combat crimes in progress, arrest or transport criminals, respond to disturbance calls, investigate suspicious persons, and from unprovoked attacks by berserk or deranged persons. $)^{16}$ In short, "in the long run, only the police can effectively take measures to prevent assaults" (Creamer and Robin, 1970: 494).

\section{NOTES}

1. For a review of the sociodemographic correlates of homicide, see for example Wolfgang (1958), Schuessler (1962), Gastil (1971), and Klebba (1975).

2. Ehrlich's (1975) examination of national execution and homicide trends during the period from 1933 to 1969 led him to conclude that the death penalty does provide an effective deterrent to murder. His research has not gone unchallenged, however, and a careful examination of his study shows it to suffer from many serious theoretical and methodological difficulties that render his findings highly suspect, at best (Passell, 1975; Passell and Taylor, 1976; Bowers and Pierce, 1975; Bailey, 1977, 1978, 1979-1980; Baldus and Cole, 1975; Forst, 1977). 
3. It is most commonly argued that capital punishment prevents police killings because the threat of possible execution deters persons from carrying lethal weapons and using them against the police when they are in danger of arrest (Sellin, 1955).

4. Sellin (1955) examined police killing rates from 1919 to 1954 for 183 cities in 11 states with capital punishment, and for 82 cities in 6 states without the death penalty. From his analysis, Sellin found police killing rates to be 1.3 per 100,000 state population in retentionist jurisdictions, and 1.2 in abolitionist jurisdictions.

5. In June of 1972, the Supreme Court ruled in Furman that "the imposition and carrying out of the death penalty in these cases constitutes cruel and unusual punishment in violation of the Eighth and Fourteenth Amendments" because it is imposed infrequently and under no clear standards (408 U.S. 283, 1972).

6. Since the early 1960 s the FBI has reported in the Uniform Crime Reports figures on police killings. These data are not broken down by state, however, which necessitated our using unpublished FBI police killing figures for the states and years considered (1961-1971). We would like to express our appreciation to the Uniform Crime Reports Division of the FBI for providing us with the necessary data for this study.

7. For the period under study, the following states did not provide for the death penalty for police killings: Alaska, Hawaii, Maine, Michigan, Minnesota, Rhode Island, and Wisconsin. In addition, a few states did not provide for the death penalty for police killings for one or more years during the 1961 to 1971 period. Delaware reinstated capital punishment on December 18, 1961, but because reenactment was in December of the year, 1961 is considered an abolition year. Oregon abolished the death penalty on November 3 , 1964, with 1965-1971 being treated as abolition years. Iowa abolished capital punishment on February 18, 1965, but because this occurred early in 1965, 1965-1971 are treated as abolition years. Finally, West Virginia abolished capital punishment on March 12, 1965 , with 1965-1971 treated as abolition years. The remaining states, Washington, D.C., Delaware (1962-1971), Oregon (1961-1964), lowa (1961-1964), and West Virginia (19611964) are treated as death penalty jurisdictions.

8 . Of interest, there is only a very slight correlation ( $\mathrm{r}$ value) between the provision for the death penalty and execution rates: $1961=.197 ; 1962=.176 ; 1963=.201 ; 1964=.127$; $1965=.101 ; 1966=.070 ; 1967=.075$. Accordingly, there are no problems of collinearity in entering the two death penalty variables in the regression analysis to be presented later (Tables 3 and 4 ).

9. For a review of the sociodemographic correlates of police killings, see Bristow (1963), Cardarelli (1968), Creamer and Robin (1970) and Meyer et al. (1979).

10. Where the required sociodemographic data were not available from the yearly Statistical Abstract of the United States, 1960 and 1970 census data were interpolated for intercensus years.

11. In some recent investigations, a log-log model has been used in examining the deterrent effect of the death penalty for murder (Ehrlich, 1975; Bowers and Pierce, 1975; Passell and Taylor, 1976). Serious questions have been raised, however, about the theoretical rationale for using log transforms (Forst, 1977), with some investigators finding similar results when the data are examined in their original form or when they are transformed. In this investigation, we do not use either a log-log or semilog model in the analysis. Because (1) death penalty and abolitionist states are differentiated by a $0 / 1$ weighting: (2) state execution rates and/or police killing rates are zero for some jurisdictions for some yeras; and (3) the log of zero cannot be taken, we examine the data in their original form.

12. Point biserial correlations are reported in Column 2 of Table 2, and productmoment correlations are reported in Column 3 . In the multiple regression analysis to be 
presented (Tables 3 and 4), weights of zero and one are assigned to abolitionist and death penalty jurisdictions, respectively.

13. A question might be raised about the possible reciprocal relationship between police killing rates and the provision/nonprovision for the death penalty for police killings. For example, a high level of police killings may result in some states passing death penalty laws. If this is true, then single equation estimates (like those used here) will result in a positive bias for the death penalty variable. For a variety of reasons, we seriously doubt that such a bias exists in the present analysis. First, we are examining police killing rates from 1961 to 1971, whereas in most states the provision/nonprovision for police killings being a capital offense is quite long-term (Bowers, 1974). Second, if such a bias were present, we would expect a rather consistent pattern in police killing rates between the two types of jurisdictions (especially during a period when the provision for capital punishment rernained a constant for most states). As discussed, this prediction is not supported by Table 1, nor are the findings presented in Table 2 (column 2) consistent with this prediction.

14. Our review of a number of police journals for recent years (Police, Law and Order, The Police Chief, F.B.I., Law Enforcement Bulletin, Enforcement Journal, and the like) has failed to reveal a single article or editorial arguing for the abolition of the death penalty. To the contrary, the retention of capital punishment and pleas for its greater use (especially for police killings) are common themes in this literature.

15. In addition, the same question can be asked about capital punishment and serious assaults on the police, especially where lethal weapons are used. As Sellin (1955) has argued, woundings are as important as actual killings, because a serious wounding may be regarded as a killing that was avoided merely by chance. Unfortunately, we have not been able to examine police woundings in this study. The FBI does publish in the annual Uniform Crime Reports some data on police assaults, but these data are not available on a state level, nor is it possible to differentiate between serious and minor assaults.

16. For example, Creamer and Robin (1970) report that for the period 1960 to 1965. there were 165 patrol officers killed in the line of duty: $32 \%$ were killed in combating crimes in progress, such as burglaries and robberies; $30 \%$ were slain attempting to arrest or transport criminals; $21 \%$ were killed responding to disturbance calls; $11 \%$ were investigating suspicious persons; and $6 \%$ lost their lives from attacks by berserk or deranged people. For later years, FBI figures also reveal a very similar pattern.

\section{CASE}

Furman v. Georgia (1972) 408 U.S. 238.

\section{REFERENCES}

BAILEY, W. C. (1979-1980) "Deterrent effect of the death penalty: an extended time series analysis." Omega 10 (3): 235-259.

(1978) "Some further evidence on imprisonment vs. the death penalty as a deterrent to murder." Law and Human Behavior 2 (3): 245-260. 
(1977) "Imprisonment vs. the death penalty as a deterrent to murder." Law and Human Behavior I (3): 239-260.

(1975) "Murder and capital punishment: some further evidence." Amer. J, of Orthopsychiatry 45 (July): 669-688.

- (1974) "Murder and the death penalty." J. of Criminal Law and Criminology 65 (3): 416-423.

BALDUS, D. and J. COLE (1975) "A comparison of the work of Thorsten Sellin and Isaac Ehrlich on the deterrent effect of capital punishment." Yale Law J. 85 (2): 170-186.

BEDAU, H. (1967) The Death Penalty In America. New York: Doubleday.

BLACK, T. and T. ORSAGH (1978) "New evidence on the efficacy of sanctions as a deterrent to homicide." Social Science Q. 58 (4): 616-631.

BOWERS, W. (1974) Executions In America. Toronto: D. C. Heath.

and G. PIERCE (1975) "The illusion of deterrence in Isaac Ehrlich's research on capital punishment." Yale Law J. 85 (December): 187-208.

BRISTOW, A. (1963) "Police officer shootings - a tactical report." J. of Criminal Law, Criminology and Police Science 54 (1): 93-95.

BYE, R. (1919) Capital Punishment in the United States. Philadelphia: Committee on Philanthropic Labor of Philadelphia Yearly Meeting of Friends.

CARDARELLI, A. (1968) "An analysis of police killed by criminal action: 1961-1963," J. of Criminal Law, Criminology and Police Science 59 (3): 447-453.

CREAMER, J. and G. ROBIN (1970) "Assaults on police," in S. Chapman (ed.) Police Patrol Readings (2nd ed.). Springfield, IL: Charles C Thomas.

DANN, R. (1935) The Deterrent Effect of Capital Punishment. Philadelphia: The Committee of Philanthropic Labor of Philadelphia Yearly Meeting of Friends.

EHRLICH, I. (1975) "The deterrent effect of capital punishment: a question of life or death." Amer. Econ. Rev. 65 (June): 397-417.

FORST, B. (1977) "The deterrent effect of capital punishment: a cross-state analysis of the 1960's." Minnesota Law Rev. 61 (May): 743-767.

GASTIL, R. (1971) "Homicide and a regional culture of violence." Amer. Soc. Rev. 36 (June): 412-427.

GIBBS, J. (1977) "A critique of the scientific literature on capital punishment and deterrence." J. of Behavioral Economics 6 ( 1 and 2): 279-309.

(1975) Crime, Punishment, and Deterrence. New York: Elsevier.

JEFFERY, C. R. (1965) "Criminal behavior and learning theory." J. of Criminal Law, Criminology and Police Science 56 (September): 294-300.

KIRKPATRICK, C. (1925) Capital Punishment. Philadelphia: Committee on Philanthropic Labor of Philadeiphia Yearly Meeting of Friends.

KLEBBA, J. (1975) "Homicide trends in the United States: 1900-74," Public Health Reports 90 (3): 195-205.

KLECK, G, (1979) "Capital punishment, gun ownership, and homicide." Amer, J. of Sociology 84 (4): $882-910$.

MEYER, K., T. MAGEDANZ, D. KIESELHORST, and S. CHAPMAN (1979) "Violence and the police: the special case of the police assault." J. of Police Science and Administration 7 (2): 161-171.

PASSELL, P. (1975) "The deterrent effect of the death penalty: a statistical test." Stanford Law Rev. 28 (November): 61-80.

and J. TAYLOR (1976) "The deterrence controversy: a reconsideration of the time series evidence," in H. Bedau and C. Pierce (eds.) Capital Punishment in the United States. New York: AMS Press.

RECKL.ESS, W. (1969) "The use of the death penalty." Crime and Delinquency 15 (1): 43-56. 
SAVITZ, L. (1958) "A study of capital punishment." J. of Criminal Law, Criminology and Police Science 49 (November-December): 338-341.

SCHUESSLER, K. (1962) "Components of variation in city crime rates," Social Problems 9 (Spring): 314-323.

(1952) "The deterrent influence of the death penalty." Annals of the American Academy of Political and Social Science 284 (November): 54-63.

SELLIN, T. (1967) Capital Punishment. New York: Harper \& Row. (1959) The Death Penalty. Philadelphia: American Law Institute.

(1955) Quoted from Royal Commission of Capital Punishment (1949-1953). Report Great Britain Parliament, (Papers by Command md. 8932) London: Her Majesty's Stationery Office: $17-24$.

SUTHERLAND, E. (1925) "Murder and the death penalty." J. of the American Institute of Criminal Law and Criminology 51: 522-529.

U.S. Department of Commerce, Bureau of the Census (1973) Census of the Population: 1970, Vol. 1: Characteristics of the Population. Washington, DC: Government Printing Office.

(1964) Census of the Population: 1960, Vol. I: Characteristics of the Population. Washington, DC: Government Printing Office.

- (1961-1972) Statistical Abstract of the United States. Washington, DC: Government Printing Office.

U.S. Department of Justice, Federal Bureau of Prisons (1971) National Prisoner Statistics: Capital Punishment, 1930-1970. Washington, DC: Government Printing Office.

(1967) National Prisoner Statistics: Executions, 1930-1966. Washington, DC: Government Printing Office.

VAN DEN HAAG, E. (1975) Punishing Criminals: Concerning a Very Old and Painful Question. New York: Basic Books.

- (1969) "On deterrence and the death penalty." J. of Criminal Law, Criminology and Police Science 60 (June): 141-147.

VOLD, G. (1932) "Can the death penalty prevent crime?" Prison J. (October): 3-8.

WOLFGANG, M. (1958) Patterns in Criminal Homicide. Philadelphia: Univ. of Pennsylvania Press.

William C. Bailey received his Ph. D. in Sociology from Washington State University and is currently Associate Professor of Sociology and Associate Dean of the Graduate College at Cleveland State University. His major research interests are in the areas of the deterrent and other preventive effects of legal sanctions, and the role of legal and extralegal factors on sanctioning practices in the adult and juvenile justice systems. 